\title{
NUMERICAL MODELING OF THE DISTRIBUTION OF SNOW LOAD ON A HYPERBOLIC PARABOLOID. THEORETICAL BASIS
}

\author{
${ }^{1}$ Surianinov M.G., Doctor of Technical Sciences, Professor, \\ sng@ogasa.org.ua, ORCID: 0000-0003-2592-5221 \\ ${ }^{1}$ Jgalli S., post-graduate student, \\ sharif.jgallin@gmail.com, ORCID: 0000-0002-1380-8039 \\ ${ }^{1}$ Al Echcheikh El Alaoui Douaa, post-graduate student, \\ doualaoui@gmail.com, ORCID: 0000-0001-8113-3822 \\ ${ }^{1}$ Odessa State Academy of Civil Engineering and Architecture \\ Didrikhson str., 4, Odesa, 65029, Ukraine
}

\begin{abstract}
The paper discusses the choice of a method for studying the distribution of snow loads on a biconcave roof of a hyperbolic paraboloid and its theoretical justification. It is noted that the numerical modeling of the aerodynamic characteristics of buildings and structures is a difficult and resource-intensive task due to the design features of building objects, which, as a rule, have a complex geometric shape, as well as due to a complex unsteady flow resulting from their flow around them. In addition, the task becomes more complicated due to the interference of vortex structures between different objects. Overcoming these objective difficulties became possible with the advent of modern specialized software systems, primarily ANSYS Fluent. Opportunities have appeared for accurate modeling with verification of the results obtained, which implies the use of an effective, well-tested mathematical apparatus. To implement the theory of two-phase flow, two methods based on numerical modeling are mainly used: the Euler-Lagrange method and the EulerEuler method. The second method is used in the work. Comparative analysis, which investigates two-phase flow around different structures using different turbulence models (including RSM model, SST k- $\omega$ model, k- $\varepsilon$ model and k-kl- $\omega$ model), shows that the $\mathrm{k}-\mathrm{kl}-\omega$ model is the best fit with experiment. ANSYS Fluent supports four multiphase models, i.e. VOF model, Mixture model, Wet Steam and Euler model. Compared to the other three models, the Mixture model provides better stability and lower computational costs, while the Euler model provides better accuracy, but at a higher computational cost . With a rather complex geometry and flow conditions, the use of the RANS approach does not lead to reliable simulation results. Moreover, unsteady turbulent flows cannot be reproduced. In real situations, landslides, saltations, and the suspended state of snow particles are closely related to the real effects of microbursts and bursts present at the surface of the boundary layer. Therefore, in further research, it is advisable to apply alternative approaches to RANS, which include Direct Numerical Simulation (DNS), Large Eddy Simulation (LES), and the hybrid RANS-LES approach to turbulence modeling, which combine efficiency LES techniques in tear-off free zones and the cost-effectiveness of RANS in near-wall areas.
\end{abstract}

Keywords: numerical modeling, snow loads, hyperbolic paraboloid, Euler-Euler method, Fluent, ANSYS.

Introduction. Long-span structures are more sensitive to unevenly distributed snow loads, which is especially inherent in light structures due to their low rigidity. In this case, uneven snow and wind loads [1] can cause sufficiently large local deformations of the roof, causing warping in the roof structure, which often leads to structural damage or even collapse.

Unfortunately, specific requirements for snow load are provided only for the design of buildings with simple roofs (e.g. flat roof, pitched or gable) in various national regulations (e.g. [2]), and few requirements exist for large-span structures. It is usually proposed to determine the coefficients of the distribution of snow load for large buildings of a special shape after specific studies or experiments in certain national standards [3, 4]. This requires an accurate account of the distribution and magnitude of climatic loads in order to correctly assess the redistribution of snow 
loads caused by the wind. There are currently three methods for assessing snowdrift, namely field observation, wind tunnel testing, and numerical simulation.

Analysis of recent research. Field observations are considered the most realistic approach [5-7], but they are highly dependent on meteorological conditions. Wind tunnel tests are more independent $[8,9]$, but they are severely limited by similarity criteria and are expensive. In recent years, computer modeling of processes in building aerodynamics has become relevant. Numerical modeling of the aerodynamic characteristics of buildings and structures is a difficult and resource-intensive task due to the design features of building objects, which, as a rule, have a complex geometric shape, as well as due to a complex unsteady flow resulting from their flow around them. In addition, the task becomes more complicated due to the interference of vortex structures between different objects. Overcoming these objective difficulties became possible with the advent of modern specialized software systems, primarily ANSYS FLUENT [10, 11]. Opportunities have appeared for accurate modeling with verification of the results obtained, which implies the use of an effective, well-tested mathematical apparatus. CFD modeling [12-14] is now widely used for parametric analysis due to its high efficiency and full-scale modeling capabilities, low cost, high accuracy, short lead times and comparative ease of use.

However, in this case, special attention should be paid to research on checking and verifying decisions $[15,16]$.

The purpose of this work is to select a method and its theoretical justification in the study of the distribution of snow loads on a biconcave roof.

Research results. Wind motion of snow and ice particles can be divided into three modes: creep, saltation, and suspension [17]. Creep is a process in which snow particles move, rolling or crawling on the surface of the snow at low wind speeds, the creep height is usually less than $0.01 \mathrm{~m}$. Saltation is when particles move along bouncing trajectories near the surface $(<10 \mathrm{~cm})$ [18], from which particles can get into turbulent eddies and switch to the mode of suspended motion [19]. If the wind speed continues to increase, the snow particles are carried upward by turbulent vortices and move far downwind, this process is called suspension, the height of the floating snow particles in suspension is about $0.1 \sim 100 \mathrm{~m}$. The snow transport speed during creep is so low that it can neglected, as in previous studies, the movement of snow during creep is not taken into account (Fig. 1).

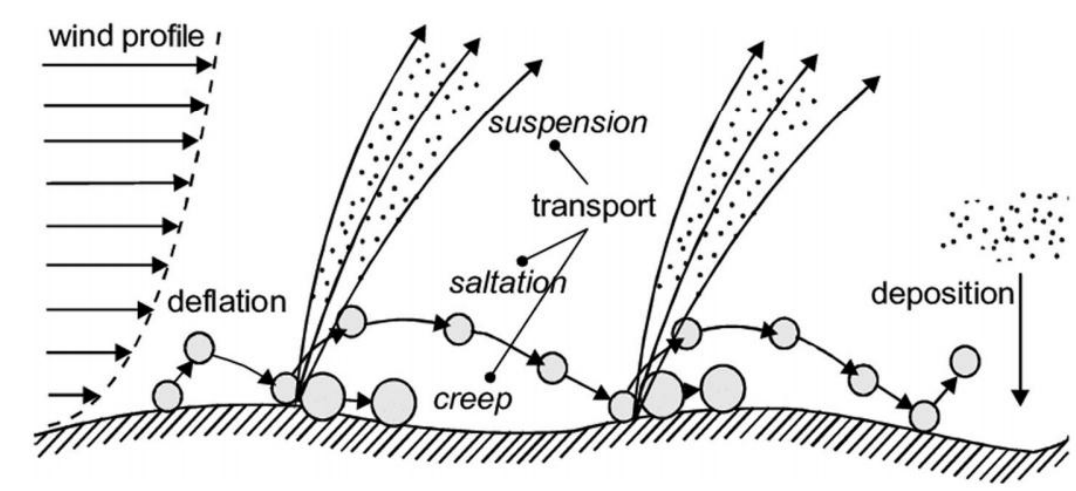

Fig. 1. Diagram showing the different phases of the wind-driven movement of snow and ice particles. Reproduced from the work of Cornelis [20]

To implement the theory of two-phase flow, two methods based on numerical modeling are mainly used: the Euler-Lagrange method and the Euler-Euler method.

The Euler-Lagrange method assumes that the phase of snow in air is discrete. Newton's law of motion is used to obtain the trajectory of a single snow particle, and then the volume of snow is distributed by integration.

The Euler-Euler method assumes that both the air and snow phases are continuous, and the problem is solved by adding the basic equation of the snow phase to the resolving equation of the air phase, and most modern numerical models of wind-induced snow drift use the Euler-Euler method. 
When simulating CFDs, the user needs to make a choice. It is well known that this choice can have a very large impact on the results. It is, of course, clear that existing wind energy practice guidelines [21-22] and general CFD applications are important and useful for simulating snowdrifts. Correct prediction of velocity fields is essential to obtain accurate snow drift calculation results.

Numerical method. Basic equations. For this simulation, the mixture model is presented as consisting of two phases, snow particles and air are considered as continuous phases. As in the Euler model, phases are considered as interpenetrating continua. The mixture model solves the equation of the momentum of the mixture and sets the relative velocities to describe the dispersed phases (1) -(3). The interaction between the phases of air and snow suggests that there is only a one-way relationship, the equations of air motion and turbulence can be considered unaffected by the air snow.

$$
\begin{gathered}
\frac{\partial \rho_{m}}{\partial t}+\nabla \cdot\left(\rho_{m} \vec{v}_{m}\right)=0^{\circ} \\
\frac{\partial\left(\rho_{m} \vec{v}_{m}\right)}{\partial t}+\nabla \cdot\left(\rho_{m} v_{m} \vec{v}_{m}\right)=-\nabla \mathrm{p}+\nabla\left[\mu_{\mathrm{m}}\left(\nabla \vec{v}_{m}+\nabla \vec{v}_{m}^{\mathrm{T}}\right)\right]+\rho_{m} \vec{g}+\vec{F} \\
\frac{\partial \rho_{s} f_{2}}{\partial t}+\nabla \cdot\left(\rho_{s} f_{2} \vec{v}_{m}\right)=0
\end{gathered}
$$

where $\rho_{m}=\sum_{k=1}^{2} \rho_{k} f_{k}$ it is the density of the mixture of air and snow: volume fraction of the air phase $(k=1)$, snow phase $(k=2), \quad \vec{v}_{m}=\sum_{k=1}^{2} \rho_{k} \vec{v}_{k} f_{k} / \rho_{m}-$ mixed phase speed, $\vec{v}_{m}=\sum_{k=1}^{2} \rho_{k} \vec{v}_{k} f_{k} / \rho_{m}-$ dynamic viscosity of the mixture, $\vec{F}$ - is body weight.

Turbulence model. In this study, the transitional model $k-k l-\omega$ is adopted. The $k-k l-\omega$ is a transitional model developed in [23]. This model uses Boussinesq's hypothesis to determine the Reynolds stress tensor. Equations (4)-(6) are solved for turbulent kinetic energy $k_{T}$, laminar kinetic energy $k_{T}$, and specific dissipation rate (turbulent time scale) $\omega$.

$$
\begin{gathered}
\frac{D k_{T}}{D t}=P_{k_{T}}+R+R_{N A T}-\mathrm{w}_{T}-\mathrm{D}_{\mathrm{T}}+\frac{\partial}{\partial \mathrm{x}_{\mathrm{j}}}\left[\left(v+\frac{\alpha_{T}}{\alpha_{k}}\right) \frac{\partial \mathrm{k}_{\mathrm{T}}}{\partial \mathrm{x}_{\mathrm{j}}}\right], \\
\frac{D k_{L}}{D t}=P_{k_{L}}-R-R_{N A T}-\mathrm{D}_{\mathrm{L}}+\frac{\partial}{\partial \mathrm{x}_{\mathrm{j}}}\left[\left(v \frac{\partial \mathrm{k}_{\mathrm{L}}}{\partial \mathrm{x}_{\mathrm{j}}}\right)\right], \\
\frac{D \omega}{D t}=C_{\omega 1} \frac{\omega}{k_{T}} P_{k_{T}}+\left(\frac{C_{\omega} R}{f_{\omega}}-1\right)\left(R+R_{N A T}\right) \frac{\omega}{k_{T}}-C_{\omega 2} \omega^{2}+ \\
+C_{\omega 3} f_{\omega} \alpha_{T} f_{w}^{2} \frac{\sqrt{k_{T}}}{\mathrm{~d}^{3}}+\frac{\partial}{\partial \mathrm{x}_{\mathrm{j}}}\left[\left(v+\frac{\alpha_{T}}{\alpha_{k}}\right) \frac{\partial \mathrm{k}_{\mathrm{T}}}{\partial \mathrm{x}_{\mathrm{j}}}\right],
\end{gathered}
$$

where $P_{k_{T}}$ and $P_{k_{L}}$ are the derived conditions of turbulence and laminar kinetic energy, respectively. $\mathrm{R}$ represents the averaged effect of the breakdown of flow fluctuations into turbulence during a bypass transfer. $R_{N A T}$ natural transition period. $\mathrm{D}_{\mathrm{T}}$ and $\mathrm{D}_{\mathrm{L}}$ wall scattering conditions.

Deposition and erosion model. Erosion or snow deposition can be modeled by calculating the snow flow at the snow surface. The erosional deposition model was developed in [13]. Erosion snow mass flow $q_{\text {ero }}$ is a function of the excess friction velocity exceeding the threshold friction velocity equation (7). Surfacing flux $q_{d e p}$ calculated in proportion to the snow concentration $f$ and the snow falling speed $w_{f}$.

$$
q_{s}=\left\{\begin{array}{c}
q_{\text {ero }}=A_{\text {ero }}\left(u_{*}^{2}-u_{*_{t}}^{2}\right) u_{*}>u_{*_{t}} \\
q_{\text {dep }}=\rho_{s} f w_{f} \frac{u_{*_{t}}^{2}-u_{*}^{2}}{u_{*_{t}}^{2}} u_{*} \leq u_{*_{t}},
\end{array}\right.
$$


where $A_{\text {ero }}$ is the coefficient of snow erosion, reflecting the adhesion strength of the snow cover; $u_{*}$ - speed of friction at the snow surface; $u_{*_{t}}$ - threshold speed of snow friction.

The value $A_{\text {ero }}=7 \times 10^{-4} \mathrm{~kg} \cdot \mathrm{m}^{4} \cdot \mathrm{s}$ was given in [13] based on calibration using field measurements by Takeuchi [24], $\mathrm{w}_{\mathrm{f}}$ is the snowfall velocity for snow particles equal to $0.2 \mathrm{~m} / \mathrm{s}$.

When the wall shear stress $\tau$ on the snow surface exceeds the threshold wall shear stress $\tau_{t}$, a snowdrift may appear. The threshold wall shear stress $\tau_{t}$ is determined by field observations, and the wall shear stress can be obtained from the logarithmic law. Here we use the friction velocity $u_{*}$ obtained from the velocity profile to replace the wall shear stress $\tau$, which obeys the following relationship:

$$
u_{*}=\sqrt{\frac{\tau}{\rho}}=\frac{\kappa u(z)}{\ln \left(\frac{z}{z_{S}}\right)},
$$

where $k$ refers to the von Karman constant equal to $0.4, z_{S}$ is the height of the aerodynamic roughness above the snow surface.

The rate of change in the height of the snow cover per unit time can be calculated as $\Delta h=q_{s} / \rho_{s}$. After a period of snow drift $\Delta \mathrm{t}$, the snow depth can be calculated using the formula:

$$
h(t)=h_{0}+\int_{0}^{\Delta t} \frac{q_{s}}{\rho_{s}} d t,
$$

where $h_{0}$ is the initial depth of the snow cover.

This robust method is only applicable to relatively small snow drifts. During sustainable simulations, erosion / deposition of snow is considered as a steady state, the rate of change in the depth of snow cover per unit time $q_{s} / \rho_{s}$ remains constant.

Thus, the time integration of equation (9) turns into the following formula.

$$
h(t)=h_{0}+\frac{q_{s}}{\rho_{s}} \Delta t .
$$

Simulation parameters. A study was carried out of the magnitude and characteristics of the distribution of the height of the snow cover on a hyperbolic paraboloid with straight edges, taking into account the change in the geometric parameters of the roof shape and the magnitude of the wind vector, which served as input parameters for the simulation.

Geometric modeling. The full-scale roof model is set up in the numerical simulation, the masts and surrounding terrain are not taken into account in the CFD simulation. Given the symmetry properties of this structure, only three wind directions $\left(0^{\circ},-45^{\circ}, 45^{\circ}\right)$ are considered for the worst case load case (Fig. 2).

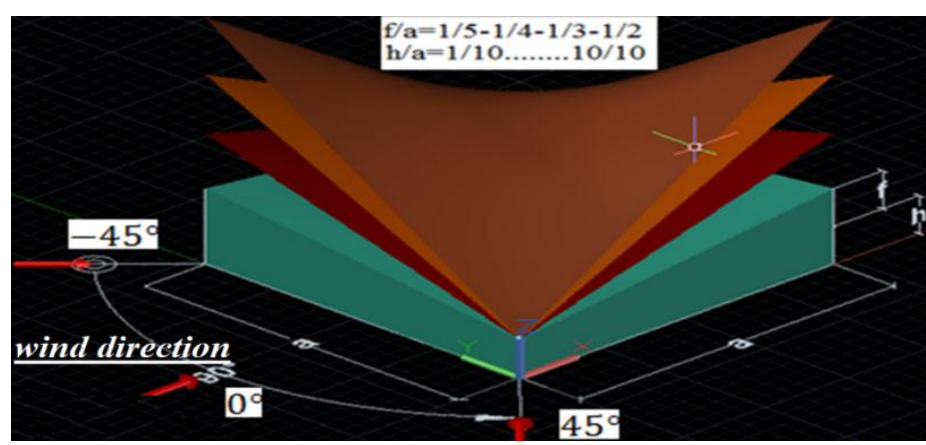

Fig. 2. Parametrization of the hypar model

The size of the computational domain is chosen as $\mathrm{X} \times \mathrm{Y} \times \mathrm{Z}=10 \mathrm{~L} \times 21 \mathrm{~B} \times 7 \mathrm{H}$, which is large enough to neglect the influence of the computational domain boundary on the internal flow field, where L, B, H refer to the roof span, width and height of the roof respectively (Fig. 3). 


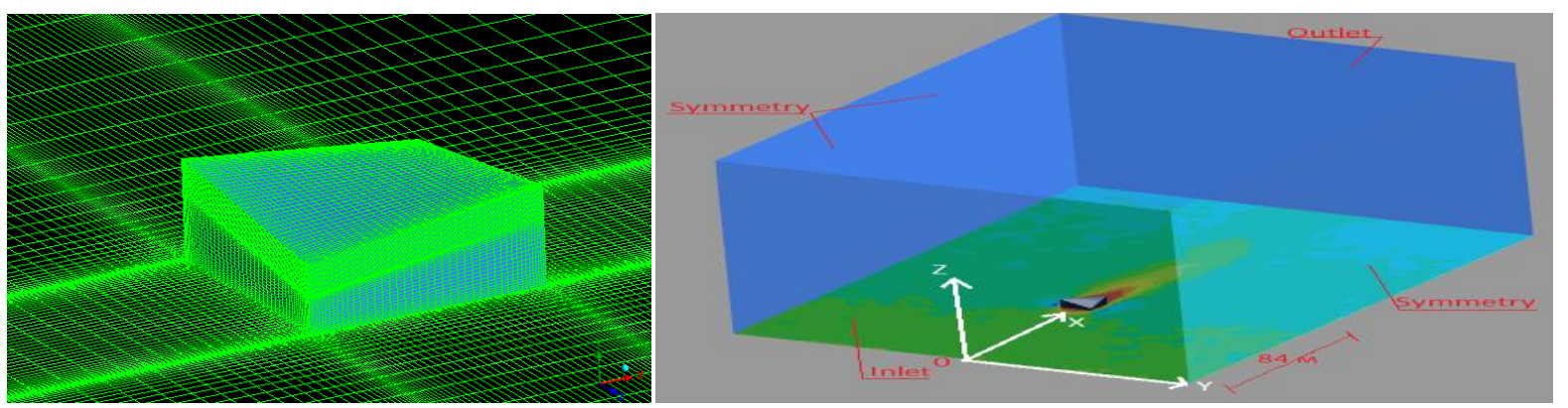

Fig. 3. Grid configurations around a hypar with 3.41 million terminal cells and a computational area

In the computational domain, the roof is modeled as a face, not a volume. Thus, the flow field around it may not be as complex as around the flow bodies, so a relatively fine mesh was used in areas far from the roof of the hypar. The computational domain is a grid of 3.41 million cells. Near the roof surface, the mesh consists of an inflatable layer with a gradually increasing mesh size with a minimum height of 0.005 , the maximum wall $y+$ is less than 30 .

Based on meteorological data provided by the Ukrainian Meteorological Data Exchange System, the average wind speed and maximum wind speed (average speed for 10 minutes at an altitude of $10 \mathrm{~m}$ ) in Odessa is $3.4 \mathrm{~m} / \mathrm{s}$ and $5.9 \mathrm{~m} / \mathrm{s}$.

Therefore, the reference wind speed $\mathrm{u}_{0}$ is chosen from 3 to $6 \mathrm{~m} / \mathrm{s}$ to create a significant snowdrift. In this study, the duration of the formation of a snowdrift $\Delta \mathrm{t}$ is taken equal to 24 hours.

Wind profile. The inlet wind speed profile is determined from the power law as follows:

$$
U(z)=U_{r e f}\left(\frac{z}{z_{r e f}}\right)^{\alpha},
$$

where $U_{\text {ref }}$ and $z_{\text {ref }}$ are the reference speed and reference altitude, respectively.

Turbulent kinetic energy profile and turbulence dissipation rate. The turbulent kinetic energy profile [25] can be determined on the basis of equation (12), while the turbulence dissipation rate $\varepsilon$ is calculated by the formula (13), where $C_{1}=-0.064, C_{2}=0.588, C_{\mu}=0.09$.

$$
\begin{aligned}
& k(z)=\sqrt{C_{1} \ln \left(z+z_{0}\right)+C_{2}}, \\
& \varepsilon(z)=C_{\mu}^{1 / 2} k(z) \frac{\partial U}{\partial z} .
\end{aligned}
$$

The length of aerodynamic surface roughness during snow transfer is calculated using an empirical equation from field measurements by Pomeroy [26]:

$$
z_{0}=0.12 u_{*}^{2} / 2 g \text {. }
$$

The specific dissipation rate $\omega$, which is used in the sensitivity analysis of the turbulence model, is calculated using equation (15):

$$
\omega=\frac{\varepsilon(\mathrm{z})}{\mathrm{C}_{\mu} \mathrm{k}(\mathrm{z})} .
$$

Snow particle concentration profile. The concentration of snow particles $\varphi$ is the product of the volume fraction of snow $f$ and the density of snow particles $\rho_{\mathrm{s}}$, the volume fraction of snow $f$ can be calculated in accordance with the system of equations (16).

$$
f=\left\{\begin{array}{c}
\frac{0.68}{g u_{*} u_{p} h_{s a l}} u_{* t}\left(u_{*}^{2}-u_{*_{t}}^{2}\right) z \leq h_{\text {sat }} \\
0.8 \exp \left[-1.55\left(4.78 u_{*}^{-0.544}-z^{-0.544}\right)\right] / \rho_{s} z>h_{\text {sat }},
\end{array}\right.
$$

where $u_{p}$ is the average speed of a snow particle in the saltation layer and is taken as $2.8 u_{* t}, h_{s a l}$ is the average height of the saltation layer, which is determined by the following equation [27]: 


$$
h_{s a l}=1.6 \frac{u_{*}^{2}}{2 g} .
$$

The conditions for the calculation are given in Table. 1.

Table 1 - Terms of calculation

\begin{tabular}{|l|l|}
\hline Amount of elements & Approximately $3,410,000$ \\
\hline Minimum cell size & $0.005 \mathrm{~m}$ \\
\hline Inflow boundary & $\begin{array}{l}\text { The wind speed profile, where U_ref is from } 3 \mathrm{~m} / \mathrm{s} \text { to } 6 \mathrm{~m} / \mathrm{s} \text {, and } \\
\text { the profile of the snow fraction is f Eq. (11-16) }\end{array}$ \\
\hline Outflow boundary & $\begin{array}{l}\text { Zero gradient condition; wind speed gradient } \partial u / \partial \mathrm{n} \text { and snow } \\
\text { fraction gradient } \partial \mathrm{f} / \partial \mathrm{n} \text { set to zero (outflow) }\end{array}$ \\
\hline Top edge and side & $\begin{array}{l}\text { Zero gradient condition for all variables; normal components of } \\
\text { wind speed with respect to the boundaries are equal to zero } \\
(\text { symmetry) }\end{array}$ \\
\hline $\begin{array}{l}\text { Structure and surface of } \\
\text { the earth }\end{array}$ & $\begin{array}{l}\text { Sticking boundary condition (wall), except that the wall roughness } \\
\mathrm{z} 0=1 \times 10^{\wedge}(-5) \text { for a snow surface }\end{array}$ \\
\hline $\begin{array}{l}\text { Convection conditions } \\
\text { discretization scheme }\end{array}$ & $\mathrm{k}-\mathrm{kl}-\omega$ model \\
\hline Turbulence model & Mixture model \\
\hline Multiphase model &
\end{tabular}

Conclusions. The accuracy of the numerical simulation of multiphase flows is compositional in nature, since the overall accuracy is due to the accuracy of each phase in an equally equal degree of importance, in particular, of two-phase flows. For example, the process of snow transfers and snow deposition, where the first phase is wind, and the second is a part of snow, and in order to obtain accurate results on snow, a correct forecast of the wind speed fields around the objects under study is necessary.

Comparative analysis, which investigates two-phase flow around different structures using different turbulence models (including RSM model, SST k- $\omega$ model, k- $\varepsilon$ model and k-kl- $\omega$ model), shows that the k-kl- $\omega$ model is the best fit with experiment.

Fluent ANSYS supports four multiphase models, that is, the VOF model, the Mixture model, the WetSteam, and the Euler model. Compared to the other three models, the Mixture model provides better stability and lower computational costs, while the Euler model provides better accuracy, but at a higher computational cost.

The process of modeling multiphase flows must be accompanied by multi-stage checks, since the physical processes can be very complex. Consequently, the accuracy and reliability of CFD modeling necessitate verification of the numerical solution and comparison with the results of an experiment in a wind tunnel or field measurements, which always remains relevant.

The rate of development of computer technology and the development of progressive numerical modeling methods in structural mechanics and fluid dynamics (CFD) in no way reduces the importance of physical tests, but only significantly reduces their number and buys time for the researcher.

With a rather complex geometry and flow conditions, the use of the RANS approach does not lead to reliable simulation results. Moreover, unsteady turbulent flows cannot be reproduced. In real situations, landslides, saltations, and the suspended state of snow particles are closely related to the real effects of microbursts and bursts present at the surface of the boundary layer. Therefore, in further studies, it is advisable to apply alternative approaches to RANS, which include Direct Numerical Simulation (DNS), Large Eddy Simulation (LES), and a hybrid RANS-LES approach to turbulence modeling that combines the efficiency of the LES technique in separation free zones and the economy of RANS in the near-wall regions. 


\section{References}

[1] T.K. Thiis, M.O' Rourke, "Model for snow loading on gable roofs", J. Struct. Eng., 141, $4015051,2015$.

[2] MOHURD. Load Code for the Design of Building Structures (GB 50009-2012), 1st ed.; China Architecture \& Building Press: Beijing, China, pp. 26-29, 2012.

[3] BSI. Eurocode 1-Actions on Structures-Part.1-3: General Actions-Snow Loads (BS EN 1991-1-3), 2nd ed.; CEN: London, UK, 2003, pp. 16-30.

[4] ASCE. Minimum Design Loads for Buildings and Other Structures (ASCE/SEI 7-10), 1st ed.; ASCE: Reston, VA, USA, 2010, pp. 29-33.

[5] AIJ. AIJ Recommendations for Loads on Buildings, 2nd ed.; AIJ: Tokyo, Japan, 2004, pp. $14-18$.

[6] D.J. Smedley, K.C.S. Kwok, D.H. Kim, "Snowdrifting simulation around Davis Station workshop", Antarctica. J. Wind Eng. Ind. Aerodyn. 50, pp. 153-162, 1993.

[7] T.K. Thiis, Y. Gjessing, "Large-scale measurements of snowdrifts around flat-roofed and single-pitch-roofed buildings", Cold Reg. Sci. Technol, 30, 1999, pp. 175-181.

[8] M. Beyers, T.M. Harms, "Outdoors modelling of snowdrift at SANAE IV Research Station", Antarctica. J. Wind Eng. Ind. Aerodyn., 91, 2003, pp. 551-569.

[9] N. Isyumov, M. Mikitiuk, "Wind tunnel model tests of snow drifting on a two-level flat roof", J. Wind Eng. Ind. Aerodyn., 36, 1990, pp. 893-904.

[10] X. Zhou, J. Hu, M. Gu, "Wind tunnel test of snow loads on a stepped flat roof using different granular materials", Nat, Hazards, 74, 2014, pp. 1629-1648.

[11] L.L. Minkov, K.M. Moiseeva, Chislennoe reshenie zadach gidrodinamiki s pomoschyu vyichislitelnogo paketa Ansys Fluent, ucheb. posobie, Tomsk: STT, 2017.

[12] Ansys Fluent Tutorial Guide, ANSYS Inc. Southpointe, 2011.

[13] T. Sato, T. Uematsu, T. Nakata, Y. Kaneda, "Three-dimensional numerical simulation of snowdrift", J. Wind Eng. Ind. Aerodyn., 46 \& 47, 1993, pp. 741-746.

[14] M. Naaim, F. Naaim-bouvet, H. Martinez, "Numerical simulation of drifting snow: erosion and deposition models", Ann. Glaciol., 26, 1998, pp. 191-196.

[15] T.K. Thiis, A.D. Ferreira, "Sheltering effect and snow deposition in arrays of vertical pillars", Environ, Fluid Mech, 15, 2015, pp. 27-39.

[16] Y. Tominaga, T. Okaze, A. Mochida, 2011a. CFD modeling of snowdrift around a building: An overview of models and evaluation of a new approach. Build. Environ. 46, 899-910.

[17] Y. Tominaga, "Computational fluid dynamics simulation of snowdrift around buildings: Past achievements and future perspectives", Cold Reg. Sci. Technol. 2017. doi.org/10.1016/j.coldregions.2017.05.004 .

[18] M. Mellor, Blowing snow, CRREL monograph, part III, Section A3c, US Army Corps of Engineers, Cold Regions Research and Engineering Laboratory, Hanover, NH, USA, 1965.

[19] D.S. Schmidt, R.A. Schmidt, J.D. Dent, "Electrostatic force in blowing snow", Bound Layer Meteorol, 93: 1999, pp. 29-45.

[20] U. Radok, "Deposition and erosion of snow by wind", US Army Cold Regions Research and Engineering Laboratory, Research Report, 230, 1968, p. 23.

[21] W.M. Cornelis, "Hydroclimatology of wind erosion in arid and semiarid environments", In: D'Odorico P, Porporato A (eds) Dryland ecohydrology. Springer, The Netherlands, 2006, pp. 141-159.

[22] J. Franke, C. Hirsch, A.G. Jensen, H.W. Krüs, M. Schatzmann, P.S. Westbury, S.D. Miles, J.A. Wisse, N.G. Wright, Recommendations on the use of CFD in wind engineering, In: van Beeck,JPAJ(Ed.), Proceedings of the International Conference on Urban Wind Engineering and Building Aerodynamics. COST ActionC14, Impact of Wind and Storm on City Life Built Environment. Von Karman Institute, Sint-Genesius-Rode, Belgium, 2004.

[23] Y. Tominaga, A. Mochida, R. Yoshie, H. Kataoka, T. Nozu, M. Yoshikawa, T. Shirasawa, "AIJ guidelines for practical applications of CFD to pedestrian wind environment around 
buildings", J. Wind Eng. Ind. Aerodyn, 96(10-11), 2008, pp. 1749-1761.

[24] D.K. Walters, J.H. Leylek, "A new model for boundary layer transition using a singlepoint RANS approach", Journal of Turbomachinery, 126, 2005, pp. 193- 202.

[25] M. Takeuchi, "Vertical profile and horizontal increase of drift-snow transport", J. Glaciol, 26, 1980, pp. 481-492.

[26] J.W. Pomeroy, D.M. Gray, "Saltation of Snow", Water Resour, 26, 1990, pp. 1583-1594.

[27]P. Richards, R. Hoxey, "Appropriate boundary conditions for computational wind engineering models using the k-e turbulence model", Journal of Wind Engineering and Industrial Aerodynamics, 46-47, 1993, pp. 145-153.

\title{
ЧИСЕЛЬНЕ МОДЕЛЮВАННЯ РОЗПОДІЛУ СНІГОВОГО НАВАНТАЖЕННЯ НА ГІПЕРБОЛІЧНОМУ ПАРАБОЛОЇДІ. ТЕОРЕТИЧНІ ОСНОВИ
}

\author{
${ }^{1}$ Сур'янінов М. Г., д.т.н., професор, \\ sng@ogasa.org.ua, ORCID: 0000-0003-2592-5221 \\ ${ }^{1}$ Jgalli S, аспірант, \\ sharif.jgallin@gmail.com, ORCID: 0000-0002-1380-8039 \\ ${ }^{1}$ Al Echcheikh El Alaoui Douaa, аспірант, \\ doualaoui@gmail.com, ORCID: 0000-0001-8113-3822 \\ ${ }^{1}$ Одеська державна академія будівництва та архітектури \\ вул. Дідріхсона, 4, м. Одеса, 65029, Україна
}

\begin{abstract}
Анотація. У роботі обговорюється вибір методу дослідження розподілу снігових навантажень на двояко увігнутому даху гіперболічного параболоїда та його теоретичне обгрунтування. Зазначається, що чисельне моделювання аеродинамічних характеристик будівель і споруд є важким і ресурсомістким завданням через конструктивні особливості будівельних об'єктів, що мають, як правило, складну геометричну форму, а також через складну нестаціонарну течію, що утворюється в результаті їх обтікання. Крім того, завдання ускладнюється внаслідок інтерференції вихрових структур між різними об'єктами. Подолання цих об'єктивних труднощів стало можливим із появою сучасних спеціалізованих програмних комплексів, насамперед ANSYS Fluent. З'явилися можливості точного моделювання 3 верифікацією отриманих результатів, що передбачає використання ефективного, добре апробованого математичного апарату. Для реалізації теорії двофазного потоку в основному використовуються два методи, що базуються на чисельному моделюванні: метод Ейлера Лагранжа та метод Ейлера - Ейлера. Діяльність використовується другий метод. Порівняльний аналіз, де досліджується обтікання різних споруд двофазним потоком із застосуванням різних моделей турбулентності (включаючи модель RSM, модель SST k- $\omega$, k- $\varepsilon$ модель та k-kl- $\omega$ ), показує, що модель k-kl- $\omega$ найкраще узгоджується з експериментом. ANSYS Fluent підтримує чотири багатофазні моделі, тобто модель VOF, модель Mixture, WetSteam та модель Ейлера. У порівнянні з рештою трьох моделей модель Mixture забезпечує кращу стабільність і менші обчислювальні витрати, в той час як модель Ейлера забезпечує кращу точність, але при великих обчислювальних витратах. За досить складної геометрії та умов перебігу використання підходу RANS не веде до достовірних результатів моделювання. Крім того, неможливо відтворити нестаціонарні турбулентні течії. У реальних ситуаціях зсуви, сальтації та зважений стан частинок снігу тісно пов'язані з реальними ефектами мікропоривів та сплесків, присутніми в поверхні прикордонного шару. Тому в подальших дослідженнях доцільно застосовувати альтернативні до RANS підходи, до яких можна віднести пряме чисельне моделювання (Direct Numerical Simulation, DNS), метод моделювання великих вихорів (Large Eddy Simulation, LES), та гібридний RANS-LES підхід до моделювання турбулентності, які поєднують у собі методики LES у відривних вільних зонах та економічність RANS у пристінних областях.

Ключові слова: чисельне моделювання, снігові навантаження, гіперболічний параболоїд, метод Ейлер-Ейлер, Fluent, ANSYS.
\end{abstract}

Bulletin of Odessa State Academy of Civil Engineering and Architecture, 2021, no. 85, page 43-51 


\title{
ЧИСЛЕННОЕ МОДЕЛИРОВАНИЕ РАСПРЕДЕЛЕНИЯ СНЕГОВОЙ НАГРУЗКИ НА ГИПЕРБОЛИЧЕСКОМ ПАРАБОЛОИДЕ. ТЕОРЕТИЧЕСКИЕ ОСНОВЫ
}

\author{
${ }^{1}$ Сурьянинов Н. Г. Д.т.н., профессор, \\ sng@ogasa.org.ua, ORCID: 0000-0003-2592-5221 \\ ${ }^{1}$ Jgalli S, аспирант, \\ sharif.jgallin@gmail.com, ORCID: 0000-0002-1380-8039 \\ ${ }^{1}$ Al Echcheikh El Alaoui Douaa, аспирант, \\ doualaoui@gmail.com, ORCID: 0000-0001-8113-3822 \\ ${ }^{1}$ Одесская государственная академия строительства и архитектуры \\ ул. Дидрихсона, 4, г. Одесса, 65029, Украина
}

\begin{abstract}
Аннотация. В работе обсуждается выбор метода исследовании распределения снеговых нагрузок на двояковогнутой крыше гиперболического параболоида и его теоретическое обоснование. Отмечается, что численное моделирование аэродинамических характеристик зданий и сооружений является трудной и ресурсоемкой задачей из-за конструктивных особенностей строительных объектов, имеющих, как правило, сложную геометрическую форму, а также из-за сложного нестационарного течения, образующегося в результате их обтекания. Кроме того, задача усложняется вследствие интерференции вихревых структур между различными объектами. Преодоление этих объективных трудностей стало возможным с появлением современных специализированных программных комплексов, в первую очередь, ANSYS Fluent. Появились возможности для точного моделирования с верификацией полученных результатов, что предполагает использование эффективного, хорошо апробированного математического аппарата. Для реализации теории двухфазного потока в основном используются два метода, основанные на численном моделировании: метод Эйлера - Лагранжа и метод Эйлера - Эйлера. В работе используется второй метод. Сравнительный анализ, где исследуется обтекание разных сооружений двухфазным потоком с применением различных моделей турбулентности (включая модель

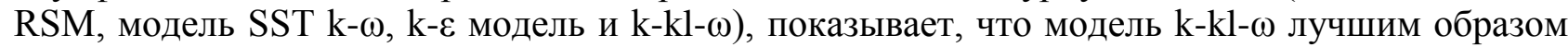
согласуется с экспериментом. ANSYS Fluent поддерживает четыре многофазные модели, то есть модель VOF, модель Mixture, WetSteam и модель Эйлера. По сравнению с остальными тремя моделями модель Mixture обеспечивает лучшую стабильность и меньшие вычислительные затраты, в то время как модель Эйлера обеспечивает лучшую точность, но при больших вычислительных затратах. При достаточно сложной геометрии и условиях течения, использование подхода RANS не ведет к достоверным результатам моделирования. Кроме того, невозможно воспроизвести нестационарные турбулентные течения. В реальных ситуациях оползни, сальтации, и взвешенное состояние частиц снега тесно связаны с реальными эффектами микропорывов и всплесков, присутствующими в поверхности пограничного слоя. Поэтому в дальнейших исследованиях целесообразно применять альтернативные к RANS подходы, к которым можно отнести прямое численное моделирование (Direct Numerical Simulation, DNS), метод моделирования крупных вихрей (Large Eddy Simulation, LES), и гибридный RANS-LES подход к моделированию турбулентности, которые сочетают в себе эффективность методики LES в отрывных свободных зонах и экономичность RANS в пристенных областях.
\end{abstract}

Ключевые слова: численное моделирование, снеговые нагрузки, гиперболический параболоид, метод Эйлера-Эйлера, Fluent, ANSYS.

Стаття надійшла до редакції 27.10.2021

Bulletin of Odessa State Academy of Civil Engineering and Architecture, 2021, no. 85, page 43-51 